\title{
PEMODELAN SEEMINGLY UNRELATED REGRESSION (SUR) PADA FAKTOR PERTUMBUHAN PEREKONOMIAN DI PROVINSI JAWA TIMUR TAHUN 2018
}

\author{
Adyria Fitriana $^{(\mathbf{1})}$, Wara Pramesti (2), Elvira Mustikawati Putri Hermanto ${ }^{(3)}$, \\ Universitas PGRI Adi Buana Surabaya \\ JL. Dukuh Menanggal XII, Surabaya 60234 \\ e-mail : adyriaf@gmail.com ${ }^{2}$,warapra@unipasby.ac.id dan elvira@unipasby.ac.id
}

\begin{abstract}
ABSTRAK
Pertumbuhan perekonomian merupakan proses perubahan kondisi perekonomian suatu wilayah secara berkesinambungan menuju keadaan yang lebih baik. Semakin tinggi tingkat pertumbuhan perekonomian, maka semakin cepat pula proses pertambahan output wilayah sehingga prospek perkembangan suatu wilayah semakin baik. Berdasarkan data BPS pada Tahun 2018 pertumbuhan perekonomian di Jawa Timur pada Tahun 2018 tumbuh sebesar 5.51\%. Hal itu tidak terlepas dari beberapa faktor ekonomi yang diantaranya didorong oleh Indeks Pembangunan Manusia (IPM) dan laju pertumbuhan Produk Domestik Regional Bruto (PDRB). Kondisi IPM di Jawa Timur tercatat pada Tahun 2018 terus mengalami kemajuan mencapai 70,77 atau tumbuh 0,72\% dibandingkan dengan Tahun 2017 yang hanya mencapai 70,27. Namun jika dilihat secara nasional, IPM di Provinsi Jawa Timur masih berada diurutan ke-15 dari 34 Provinsi di Indonesia. Jika dibandingkan dengan beberapa Provinsi di Pulau Jawa, IPM di Provinsi Jawa Timur menjadi yang terendah. Laju pertumbuhan PDRB di Indonesia pada Tahun 2018 mencapai 5,17\%, dimana angka tersebut lebih tinggi dibandingkan Tahun 2017 yang hanya mencapai 5,07\%. Di tengah kondisi laju pertumbuhan PDRB Indonesia yang meningkat, justru kondisi laju pertumbuhan PDRB di Provinsi Jawa Timur mengalami penurunan dari Tahun 2017 sebesar 5,64\% menjadi 5,5 $\%$ pada Tahun 2018. Hal ini juga menempatkan Provinsi Jawa Timur pada peringkat terakhir dari jumlah Provinsi yang ada di Pulau Jawa setelah Jawa Tengah. Penelitian ini dilakukan untuk menerapkan metode Seemingly Unrelated Regression (SUR) pada pemodelan IPM dan laju pertumbuhan PDRB sebagai faktor pertumbuhan perekonomian di Jawa Timur. Seemingly Unrelated Regression (SUR) merupakan pengembangan dari model regresi linier yang mampu mengakomodasi adanya korelasi antara error suatu persamaan dengan error persamaan lain. Berdasarkan hasil pemodelan SUR, diketahui bahwa variabel yang berpengaruh pada IPM ( $\mathrm{Y}_{1}$ ) adalah variabel Upah Minimum $\left(\mathrm{X}_{1}\right)$ dan Jumlah Angkatan Kerja $\left(\mathrm{X}_{4}\right)$, sedangkan variabel yang berpengaruh pada laju pertumbuhan PDRB $\left(\mathrm{Y}_{2}\right)$ adalah variabel Upah Minimum $\left(\mathrm{X}_{1}\right)$. Penggunaan model SUR menghasilkan koefisien determinasi $\left(\mathrm{R}^{2}\right)$ Mc-Elroy sebesar 46,1\%.
\end{abstract}

Kata Kunci: Mc-Elroy, $R^{2}$, Seemingly Unrelated Regression (SUR).

\begin{abstract}
Economic growth is a process of changing the economic conditions of a region on an ongoing basis towards better conditions. The higher the rate of economic growth, the faster the process of increasing regional output so that the prospects for the development of a region are better. Based on BPS data in 2018 economic growth in East Java in 2018 grew by $5.51 \%$. It is not independent of several economic factors which among others are driven by the Human Development Index (HDI) and the growth rate of Gross Regional Domestic Product (GRDP). The HDI conditions in East Java recorded in 2018 continued to experience progress reaching 70.77 or growing 0.72\% compared to 2017 which only reached 70.27. However, when viewed nationally, HDI in East Java Province is still ranked 15th out of 34 Provinces in Indonesia. When compared with some provinces in Java, the HDI in East Java Province is the lowest.The GDP growth rate in Indonesia in 2018 reach 5.17\%, which is higher than in 2017 which only reached 5.07\%. In the
\end{abstract}

Adyria Fitriana $^{1}$, Wara Pramesti ${ }^{2}$, Elvira Mustikawati Putri Hermanto ${ }^{3}$, 
midst of Indonesia's increasing GDP growth rate, the GDP growth rate in East Java Province has decreased from 2017 by 5.64\% to 5.5\% in 2018. This also places East Java Province in the last rank of total Provinces in Java after Central Java. This research was conducted to apply the Seemingly Unrelated Regression (SUR) method to the HDI modeling and GRDP growth rate as a factor for economic growth in East Java. Seemingly Unrelated Regression (SUR) is the development of a linear regression model that is able to accommodate the correlation between an error in an equation and an error in another equation. Based on the results of SUR modeling, it is known that the variables that influence the HDI $\left(Y_{1}\right)$ are the Minimum Wage variable $\left(X_{I}\right)$ and the Total Labor Force $\left(X_{4}\right)$, while the variables that affect the GRDP growth rate $\left(Y_{2}\right)$ are the Minimum Wage variable $\left(X_{1}\right)$. The use of the SUR model produces a Mc-Elroy determination coefficient $\left(R^{2}\right)$ of $46.1 \%$.

\section{Keywords: Mc-Elroy, $R^{2}$, Seemingly Unrelated Regression (SUR.}

\section{PENDAhuluan}

Pertumbuhan perekonomian merupakan proses perubahan kondisi perekonomian suatu negara secara berkesinambungan menuju keadaan yang lebih baik selama periode tertentu. Adanya pertumbuhan perekonomian suatu negara merupakan indikasi keberhasilan suatu pembangunan ekonomi dalam kehidupan masyarakat. Pertumbuhan perekonomian Indonesia pada Tahun 2018 mencapai 5,17\% angka itu lebih tinggi dibandingkan pertumbuhan ekonomi pada Tahun 2017 dan 2016 yang hanya mencapai 5,07\% dan 5,03\% (BPS, 2019). Seperti halnya kemajuan pertumbuhan perekonomian di Jawa Timur pada Tahun 2018 tumbuh sebesar 5,51\%. Hal itu tidak terlepas dari beberapa faktor ekonomi yang diantaranya didorong oleh Indeks Pembangunan Manusia (IPM) dan Produk Domestik Regional Bruto (PDRB) (BPS, Jatim,2019).

Indeks Pembangunan Manusia (IPM) menjadi salah satu ukuran kualitas yang dapat digunakan untuk mengetahui sejauh mana kualitas pembangunan manusia telah berhasil dicapai. Seperti halnya kondisi IPM di Jawa Timur tercatat pada Tahun 2018 terus mengalami kemajuan mencapai 70,77 atau tumbuh $0,72 \%$ dibandingkan dengan Tahun 2017 yang hanya mencapai 70,27. Namun jika dilihat secara nasional, IPM di Jawa Timur masih berada diurutan ke-15 dari 34 Provinsi di Indonesia. Jika dibandingkan dengan beberapa Provinsi di Pulau Jawa, IPM Jawa Timur menjadi yang terendah(BPS, Jatim,2019).

Laju pertumbuhan PDRB merupakan ukuran pertumbuhan ekonomi dari satu periode ke periode lain menggunakan persentase indikator yang digunakan untuk mengatur sejauh mana keberhasilan pemerintah memanfaatkan sumber daya yang ada dan digunakan sebagai perencanan pengambilan keputusan yang timbul dari seluruh sektor perekonomian di suatu wilayah. Berdasarkan data Kementerian Perekonomian dan Pembangunan Indonesia tercatat bahwa laju pertumbuhan PDRB di Indonesia pada Tahun 2018 mencapai 5,17\%, dimana angka tersebut lebih tinggi dibandingkan Tahun 2017 yang hanya mencapai $5,07 \%$. Sedangkan ditengah kondisi laju pertumbuhan PDRB Indonesia yang meningkat, justru kondisi laju pertumbuhan PDRB di Provinsi Jawa Timur mengalami penurunan dari Tahun 2017 sebesar 5,64\% menjadi 5,5\% pada Tahun 2018. Hal ini menempatkan Provinsi Jawa Timur pada peringkat terakhir dari jumlah Provinsi yang ada di Pulau Jawa setelah Jawa Tengah (BPS Jatim, 2019).

Seemingly Unrelated Regression (SUR) dikembangkan oleh (Zellner, 1962) yang merupakan pengembangan dari model regresi linier. SUR merupakan suatu sistem persamaan yang terdiri dari beberapa persamaan regresi, dimana setiap persamaan memiliki variabel respon yang berbeda dan dimungkinkan memiliki himpunan variabel prediktor yang berbeda-beda pula. Kelebihan dari sistem persamaan SUR adalah mampu mengakomodasi adanya korelasi antara error suatu persamaan dengan error persamaan lain. Selain itu, model SUR lebih efisien karena estimasi parameter dilakukan secara serempak dan melibatkan korelasi kesebayaan. Korelasi kesebayaan terjadi apabila pada unit waktu yang sama, namun pada error persamaan yang berbeda saling berkorelasi. 
Berbagai penelitian telah dilakukan seperti pada Tahun 2011 penelitian yang dilakukan oleh Samad Rumaelan yang berjudul "Pemodelan ketahanan pangan rumah tangga di Indonesia dengan pendekatan SUR"dan diperoleh hasil bahwa variabel-variabel ketahanan pangan mempengaruhi derajat ketahanan pangan rumah tangga di Indonesia. Hal ini ditunjukkan dengan nilai koefisien regresi terbesarnya dan didapatkan 3 model persamaan SUR. Kemudian pada tahun 2013 penelitian juga dilakukan oleh Agus Budhi Santosa yang berjudul "Seemingly Unrelated Regression dengan pendekatan Bayesian pada sektor utama di Jawa Timur". Menjelaskan bahwa metode SUR banyak digunakan dalam menyelesaikan beberapa persamaan regresi dimana masing-masing persamaan memiliki parameter sendiri dan Nampak bahwa tiap persamaan tidak berhubungan. Namun demikian, antar persamaan tersebut terjadi kaitan satu sama lainnya yaitu dengan adanya korelasi antar error dalam persamaan yang berbeda.

Berdasarkan penjelasan tersebut, maka pada penelitian ini akan dilakukan pemodelan faktor perekonomian di Provinsi Jawa Timur yang didorong oleh IPM dan laju pertumbuhan PDRB dari berbagai Kabupaten/Kota yang ada di Provinsi Jawa Timur. Dengan menggunakan metode SUR diharapkan dapat menjelaskan dan mengidentifikasi faktor - faktor yang mempengaruhi perekonomian di Provinsi Jawa Timur berdasarkan 2 persamaan model sekaligus.

\section{METODOLOGI PENELITIAN}

\subsection{Sumber Data dan Variabel Penelitian}

Data yang digunakan dalam penelitian ini adalah data sekunder yang diperoleh dari Publikasi Badan Pusat Statistik Provinsi Jawa Timur yang berjudul "Provinsi Jawa Timur dalam Angka 2020", "Statistika Keuangan Pemerintah Desa 2018", dan "Perkembangan Beberapa Indikator Utama Sosial-Ekonomi Provinsi Jawa Timur 2019". Unit observasi penelitian ini adalah 29 Kabupaten dan 9 Kota di Provinsi Jawa Timur.

Variabel-variabel yang digunakan pada penelitian ini adalah Indeks Pembangunan Manusia $\left(\mathrm{Y}_{1}\right)$ dan Laju Pertubuhan Produk Domestik Regional Bruto $\left(\mathrm{Y}_{2}\right)$. Sedangkan variabel prediktor yang digunakan dalam penelitian ini adalah Upah Minimum $\left(\mathrm{X}_{1}\right)$, Pendapatan Asli Daerah $\left(\mathrm{X}_{2}\right)$, Jumlah Investasi Pada Industri Besar dan Sedang $\left(\mathrm{X}_{3}\right)$, Jumlah Angkatan Kerja $\left(\mathrm{X}_{4}\right)$, dan Tingkat Partisipasi Angkatan Kerja $\left(\mathrm{X}_{5}\right)$

\subsection{Metode Penelitian}

Langkah analisis yang digunakan dalam penelitian ini adalah sebagai berikut:

1. Mendeskripsikan masing-masing variabel dalam penelitian sebagai gambaran faktor pertumbuhan perekonomian di Jawa Timur.

2. Memodelkan regresi OLS untuk masing-masing persamaan.

3. Memeriksa asumsi residual model OLS

4. Menguji korelasi kesebayaan antar error model.

5. Memodelkan pemodelan SUR

6. Memeriksa asumsi residual model SUR.

7. Mengintepretasikan ketepatan model SUR.

8. Kesimpulan

\section{HASIL DAN PEMBAHASAN}

\subsection{Analisis Deskriptif}

Pada bagian ini akan dijelaskan mengenai gambaran umum faktor perekonomian menurut Kabupaten/Kota di Provinsi Jawa Timur 2018 yang meliputi IPM dan laju pertumbuhan PDRB beserta variabel prediktor yang diduga mempengaruhinya yang akan dideskripsikan Pada Tabel 1. Hasil analisis deskriptif menunjukkan bahwa nilai maksimum dan minimum untuk masingmasing variabel. Selisih antara nilai maksimum dan minimum yang besar menunjukkan adanya perbedaan kondisi di masing-masing Kabupaten/Kota. Berdasarkan data BPS, rata-rata IPM Jawa Timur mengalami kenaikan dari Tahun 2017 sebesar 70,27 menjadi sebesar 70,77 pada Tahun 2018 dengan IPM tertinggi berada pada kota Surabaya sebesar 81,74 dan terendah pada Kabupaten Sampang sebesar 61,00, sehingga IPM di Kota Surabaya memiliki selisih yang sangat jauh dibandingkan dengan IPM di Kabupaten Sampang. Hal ini disebabkan karena perbedaan angka capaian IPM yang cukup besar dipengaruhi oleh kondisi masing-masing daerah yang berbeda.

Tabel 1.Analisis Deskriptif

Adyria Fitriana $^{1}$, Wara Pramesti ${ }^{2}$, Elvira Mustikawati Putri Hermanto ${ }^{3}$, 


\begin{tabular}{rrrrr}
\hline & \multicolumn{1}{c}{ Mean } & \multicolumn{1}{c}{ Stdev } & \multicolumn{1}{l}{ Max } & \multicolumn{1}{l}{ Min } \\
\hline $\mathbf{Y}_{\mathbf{1}}$ & 70,97 & 5,21 & 81,74 & 61,00 \\
\hline $\mathbf{Y}_{\mathbf{2}}$ & 5,41 & 0,49 & 6,50 & 4,26 \\
\hline $\mathbf{X}_{\mathbf{1}}$ & 21652 & 4774 & 34056 & 15623 \\
& 18,16 & 49,38 & 33,00 & 40,00 \\
\hline $\mathbf{X}_{\mathbf{2}}$ & 2,35 & 1,33 & 81,71 & 8,72 \\
\hline $\mathbf{X}_{\mathbf{3}}$ & 1743,55 & 714,96 & 2927,00 & 594 \\
\hline $\mathbf{X}_{\mathbf{4}}$ & 5605 & 3469 & 15200 & 685 \\
& 37,45 & 13,79 & 41,00 & 12,00 \\
\hline $\mathbf{X}_{\mathbf{5}}$ & 69,69 & 3,40 & 79,41 & 64,41
\end{tabular}

sebaran PDRB Kabupaten/ Kota di Jawa Timur yang digambarkan dengan gradien warna hijau muda hingga hijau tua yang mengindikasikan semakin gelap warna Kabupaten/Kota, maka semakin rendah laju pertumbuhan PDRB.. Jumlah PDRB di Jawa timur pada tahun 2018 sebesar 569,39 triliun rupiah dengan PDRB tertinggi berada pada Kota Surabaya sebesar 538954,46 dan terendah pada Kota Blitar sebesar 6302,33.

Laju pertumbuhan PDRB rendah menyebar pada sebagian Pulau Madura serta Kabupaten Bojonegoro, Probolinggo, dan Kota Probolinggo. Sedangkan daerah dengan laju pertumbuhan PDRB sedang hampir menyebar pada sebagian besar Jawa Timur. Sementara itu, daerah dengan laju pertumbuhan PDRB tinggi menyebar pada bagian utara wilayah Jawa Timur dan Kabupaten Banyuwangi. mengindikasikan semakin gelap warn Kabupaten/Kota, maka semakin rendah capaian IPM. Rata-rata IPM Jawa Timur mengalami kenaikan dari Tahun 2017 sebesar 70,27 menjadi sebesar 70,77 pada Tahun 2018 dengan IPM tertinggi berada pada kota Surabaya sebesar 81,74 dan terendah pada Kabupaten Sampang sebesar 61,00.

Dimana Kabupaten/Kota dengan IPM rendah menyebar pada bagian timur Provinsi Jawa Timur dan keseluruhan Pulau Madura serta Kabupaten Tuban, Bojonegoro, dan Pacitan. Sedangkan daerah dengan IPM sedang hampir mengelompok pada bagian selatan hingga sebagian utara Provinsi Jawa Timur, serta bagian ujung timur yakni Kabupaten Banyuwangi. Sementara itu, daerah dengan IPM tinggi menyebar pada sebagian utara Provinsi Jawa Timur hingga bagian selatan yakni Kota Blitar dan Kota Malang.

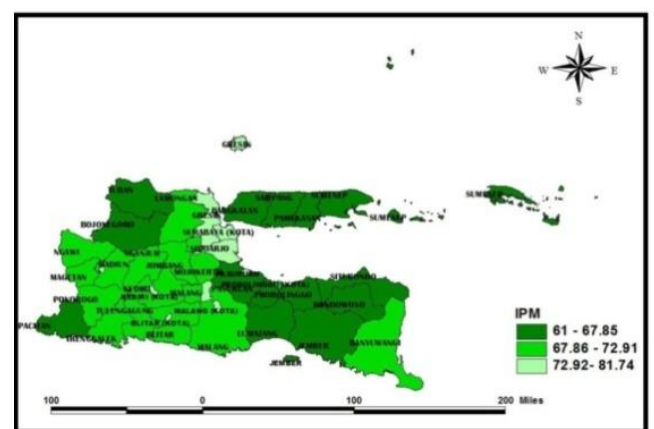

Gambar 1. Peta Persebaran IPM di Kabupaten/Kota Provinsi Jawa Timur 2018

Gambar 2 menunjukkan pemetaan

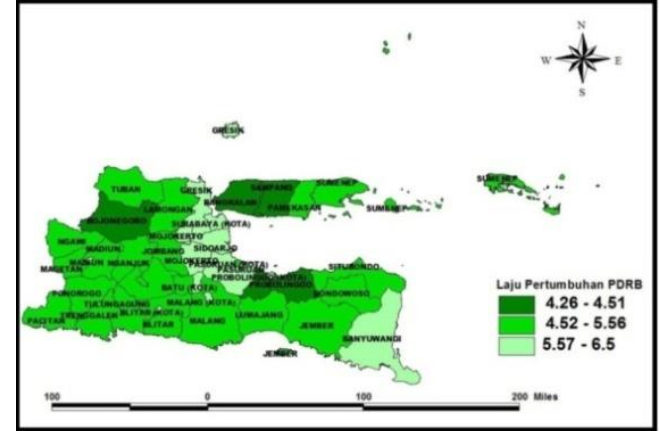

Gambar 2. Peta Persebaran Laju Pertumbuhan PDRB di Kabupaten/Kota Provinsi Jawa Timur 2018

\subsection{Regresi Ordinary Least Square (OLS)}

Sebelum menganalisis data dengan metode SUR, terlebih dahulu dilakukan analisis regresi dengan menggunakan OLS untuk memperoleh error dari masing-masing persaman. Tabel 2 menunjukkan hasil dari analisis regresi OLS dari 2 variabel respon dan faktor-faktor yang diduga mempengaruhinya.

\begin{tabular}{|c|c|c|c|c|}
\hline & \multicolumn{2}{|c|}{ IPM } & \multicolumn{2}{|c|}{ Laju PDRB } \\
\hline & $\begin{array}{c}\text { Parame } \\
\text { ter }\end{array}$ & p-value & $\begin{array}{c}\text { Parame } \\
\text { ter }\end{array}$ & p-value \\
\hline int & $5,613 \mathrm{e}^{+01}$ & $* 2 \mathrm{e}^{-16}$ & $3,62 \mathrm{e}^{+00}$ & $* 0,026$ \\
\hline $\mathbf{X}_{1}$ & $7,291 \mathrm{e}^{-06}$ & $* 4,73 \mathrm{e}^{-06}$ & $6.305 \mathrm{e}^{-07}$ & $* 0,000$ \\
\hline $\mathbf{X}_{2}$ & $1,619 \mathrm{e}^{-17}$ & 0,099 & - & - \\
\hline $\mathbf{X}_{3}$ & - & - & $-1,040 \mathrm{e}^{-04}$ & 0,288 \\
\hline $\mathbf{X}_{4}$ & $-8,127 \mathrm{e}^{-06}$ & $* 0,021$ & - & - \\
\hline
\end{tabular}

Adyria Fitriana $^{1}$, Wara Pramesti ${ }^{2}$, Elvira Mustikawati Putri Hermanto ${ }^{3}$, 
Tabel 2. Regresi OLS (Lanjutan)

\begin{tabular}{ccccc}
\hline \multicolumn{2}{c}{ IPM } & \multicolumn{3}{c}{ Laju PDRB } \\
\hline $\begin{array}{c}\text { Parame } \\
\text { ter }\end{array}$ & p-value & $\begin{array}{c}\text { Parame } \\
\text { ter }\end{array}$ & p-value \\
\hline $\mathbf{X}_{\mathbf{5}}$ & - & - & $8,600 \mathrm{e}^{-03}$ & 0,682 \\
\hline $\mathrm{R}^{2}$ & \multicolumn{3}{c}{0,599} & \multicolumn{2}{c}{0,299} \\
\hline Keterangan: *) Signifikan pada $\alpha=5 \%$
\end{tabular}

Berdasarkan Tabel 2 dapat diperoleh model OLS dari masing-masing variabel respon dan faktor-faktor yang diduga mempengaruhinya sebagai berikut:

$$
\begin{gathered}
\widehat{Y}_{1}=5,613 \mathrm{e}^{+01}+7,291 \mathrm{e}^{-06} X_{1}+1,619 \mathrm{e}^{-17} X_{2} \\
-8,127 \mathrm{e}^{-06} X_{4} \\
\widehat{Y}_{2}=3,62 \mathrm{e}^{+00}+6,305 \mathrm{e}^{-07} X_{1}-1,040 \mathrm{e}^{-04} X_{3} \\
+8,600 \mathrm{e}^{-03} X_{5}
\end{gathered}
$$

Berdasarkan model regresi OLS dapat menjelaskan bahwa:

Untuk model $\hat{Y}_{1}$

- Jika variabel upah minimum $\left(X_{1}\right)$ naik sebesar satu rupiah maka IPM ( $\left.\mathrm{Y}_{1}\right)$ akan naik sebesar 7,291e $\mathrm{e}^{-06}$. Jika variabel jumlah angkatan kerja $\left(\mathrm{X}_{4}\right)$ bertambah satu orang maka IPM $\left(\mathrm{Y}_{1}\right)$ akan turun sebesar $8,127 \mathrm{e}^{-06}$ dan variabel prediktor yang berpengaruh signifikan terhadap IPM $\left(\mathrm{Y}_{1}\right)$ adalah upah minimum $\left(\mathrm{X}_{1}\right)$ dan Jumlah Angkatan Kerja $\left(\mathrm{X}_{4}\right)$ karena nilai $p$-value dari kedua variabel tersebut lebih kecil dari nilai alpha $5 \%$.

Untuk model $\hat{Y}_{2}$

- Jika variabel upah minimum $\left(\mathrm{X}_{1}\right)$ naik sebesar satu rupiah maka laju pertumbuhan PDRB $\left(\mathrm{Y}_{2}\right)$ akan naik sebesar $6.305 \mathrm{e}^{-07}$ dan variabel prediktor yang berpengaruh signifikan terhadap laju pertumbuhan $\operatorname{PDRB}\left(\mathrm{Y}_{2}\right)$ adalah upah minimum $\left(\mathrm{X}_{1}\right)$ karena nilai $p$-value dari variabel tersebut lebih kecil dari nilai alpha $5 \%$.

Pada Tabel 2 juga di dapatkan nilai $\mathrm{R}^{2}$ untuk model $\hat{Y}_{1}$ sebesar 0,599 berarti $59,9 \%$ IPM dapat dijelaskan oleh upah minimum, pendapatan asli daerah, dan jumlah angkatan kerja. Sedangkan untuk nilai $\mathrm{R}^{2}$ untuk model $\hat{Y}_{2}$ sebesar 0,299 berarti 29,9\% laju pertumbuhan PDRB dapat dijelaskan oleh upah minimum, jumlah investasi pada industri besar dan sedang, dan tingkat partisipasi angkatan kerja.

\subsection{Uji Asumsi Residual Regresi OLS}

Setelah dilakukan pemodelan regresi OLS, maka perlu dilakukan pengujian asumsi residual Identik, Independen, dan Distribusi Normal (IIDN).

\subsubsection{Uji Homoskedastisitas}

Pada Tabel 3 menunjukkan hasil pengujian homoskedastisitas dengan menggunakan uji Breush-Pagan.

\begin{tabular}{cccc}
\multicolumn{3}{c}{ Tabel 3. Breush Pagan Test } \\
\hline & $\begin{array}{c}\text { Breush- } \\
\text { Pagan }\end{array}$ & p-value & Keputusan \\
\hline$\widehat{\boldsymbol{Y}}_{\mathbf{1}}$ & 2,308 & $* \mathbf{0 , 5 1 1}$ & $\begin{array}{c}\text { Gagal } \\
\text { Tolak } \mathrm{H}_{0}\end{array}$ \\
& & & Gagal \\
$\widehat{\boldsymbol{Y}}_{\mathbf{2}}$ & 7,525 & $* \mathbf{0 , 0 5 7}$ & Tolak $\mathrm{H}_{0}$ \\
\hline
\end{tabular}

Keterangan: *) Signifikan pada $\alpha=5 \%$

Berdasarkan Tabel 3 untuk model $\hat{Y}_{1}$ dan $\hat{Y}_{2}$ diperoleh nilai $p$-value yang lebih besar dari $\alpha=5 \%$.Sehingga dapat dikatakan ragam error dari kedua model homogen dan telah memenuhi asumsi identik.

\subsubsection{Uji Autokorelasi}

Pada Tabel 4 menunjukkan hasil pengujian autokorelasi dengan menggunakan uji Run Test.

\begin{tabular}{cccc}
\multicolumn{4}{c}{ Tabel 4. Run Test } \\
\hline & $\begin{array}{l}\text { Durbin } \\
\text { Watson }\end{array}$ & p-value & Keputusan \\
\hline$\widehat{\boldsymbol{Y}}_{\mathbf{1}}$ & 0,000 & $* \mathbf{1 , 0 0 0}$ & Gagal Tolak $\mathrm{H}_{0}$ \\
\hline$\widehat{\boldsymbol{Y}}_{\mathbf{2}}$ & $-0,823$ & $* \mathbf{0 , 4 1 1}$ & Gagal Tolak $\mathrm{H}_{0}$
\end{tabular}

Keterangan: *) Signifikan pada $\alpha=5 \%$

Berdasarkan Tabel 4 untuk model $\hat{Y}_{1}$ dan $\hat{Y}_{2}$ diperoleh nilai $p$-value yang lebih besar dari $\alpha=5 \%$. Sehingga dapat dikatakan bahwa error dari kedua model tidak terdapat autokorelasi dan telah memenuhi asumsi independen.

\subsubsection{Uji Normalitas}

Pada Tabel 5 menunjukkan hasil pengujian pengujian asumsi distribusi normal dengan menggunakan uji kolmogorovsmirnov.

Tabel 5. Kolmogorov-Smirnov Test

\begin{tabular}{cccc}
\hline & Nilai $\boldsymbol{D}$ & $\boldsymbol{p}$-value & Keputusan \\
\hline$\widehat{\boldsymbol{Y}}_{\mathbf{1}}$ & 0,058 & $\boldsymbol{* 0 , 9 8 7}$ & Gagal Tolak \\
& & & $\mathrm{H}_{0}$ \\
\hline$\widehat{\boldsymbol{Y}}_{\mathbf{2}}$ & 0,141 & $\boldsymbol{* 0 , 0 5 4}$ & $\begin{array}{c}\text { Gagal Tolak } \\
\mathrm{H}_{0}\end{array}$ \\
\hline
\end{tabular}

Keterangan: *) Signifikan pada $\alpha=5 \%$

Berdasarkan Tabel 5 untuk model $\hat{Y}_{1}$ dan $\hat{Y}_{2}$ diperoleh nilai $p$-value yang lebih besar dari $\alpha=5 \%$. Sehingga dapat dikatakan

Adyria Fitriana $^{1}$, Wara Pramesti ${ }^{2}$, Elvira Mustikawati Putri Hermanto ${ }^{3}$, 
bahwa error dari kedua model berdistribusi normal dan telah memenuhi asumsi distribusi normal.

\subsection{Model SUR dengan Metode GLS}

Setelah memperoleh persamaan regresi linier dengan menggunakan OLS, selanjutnya menggunkan error pada persamaan regresi yang telah diperoleh untuk memperoleh estimasi dari varian-kovarian $\sigma_{i j}$. Setelah dilakukan perhitungan tersebut diperoleh matriks varian-kovarians pada Tabel 6 sebagai berikut:

\begin{tabular}{ccc}
\multicolumn{4}{c}{ Tabel 6. Matriks Kovarian antar Error Model } \\
\hline & $\widehat{\boldsymbol{Y}}_{\mathbf{1}}$ & $\widehat{\boldsymbol{Y}}_{\mathbf{2}}$ \\
\hline$\widehat{\boldsymbol{Y}}_{\mathbf{1}}$ & 11,013 & 0,727 \\
\hline$\widehat{\boldsymbol{Y}}_{\mathbf{2}}$ & 0,727 & 0,175 \\
\hline
\end{tabular}

Untuk mengetahui ada tidaknya korelasi kesebayaan dapat dilakukan dengan uji Lagrange Multiplier, maka diperoleh nilai $\lambda$ $=10,442$. Dengan tingkat signifikansi $\alpha=5 \%$, diperoleh keputusan tolak $\mathrm{H}_{0}$ karena nilai $\lambda$ lebih besar dari nilai $\chi_{(1 ; 0.05)}^{2}=3,841$. Sehingga dapat disimpulkan bahwa terdapat korelasi kesebayaan antara galat dari persamaan yang berbeda.

Estimasi model SUR dengan pendekatan estimasi GLS diperoleh hasil sebagai berikut:

Tabel 7. Model SUR dengan Estimasi GLS

\begin{tabular}{ccrrr}
\hline & \multicolumn{2}{c}{ IPM } & \multicolumn{2}{c}{ Laju PDRB } \\
\hline & $\begin{array}{c}\text { Parame- } \\
\text { ter }\end{array}$ & P-Value & $\begin{array}{c}\text { Paramete } \\
\mathbf{r}\end{array}$ & $\begin{array}{c}\boldsymbol{P} \text { - } \\
\text { Value. }\end{array}$ \\
\hline $\begin{array}{c}\text { In } \\
\mathbf{t}\end{array}$ & $5,542 \mathrm{e}^{+01}$ & $* \mathbf{2 , 2 2} \mathrm{e}^{-16}$ & $2,567 \mathrm{e}^{+00}$ & $* \mathbf{0 , 0 0 7}$ \\
\hline $\mathbf{X}_{\mathbf{1}}$ & $7,722 \mathrm{e}^{-06}$ & $* \mathbf{1 , 0 5 3} \mathrm{e}^{-06}$ & $6,483 \mathrm{e}^{-07}$ & $* \mathbf{0 , 0 0 0}$ \\
\hline $\mathbf{X}_{\mathbf{2}}$ & $1,012 \mathrm{e}^{-17}$ & 0,240 & - & - \\
\hline $\mathbf{X}_{\mathbf{3}}$ & - & - & $-6,207 \mathrm{e}^{-05}$ & 0,488 \\
\hline $\mathbf{X}_{\mathbf{4}}$ & $-6,120 \mathrm{e}^{-06}$ & $* \mathbf{0 , 0 4 9}$ & - & - \\
\hline $\mathbf{X}_{\mathbf{5}}$ & - & - & $2,219 \mathrm{e}^{-02}$ & 0,238 \\
\hline $\mathrm{R}^{2}$ & \multicolumn{5}{l}{0,285} \\
\hline Keterangan: $\left.{ }^{*}\right)$ Signifikan pada $\alpha=5 \%$
\end{tabular}

Berdasarkan Tabel 7 dapat diperoleh model SUR dari masing-masing variabel respon dan faktor-faktor yang diduga mempengaruhinya sebagai berikut:

$$
\begin{gathered}
\widehat{Y}_{1}=5,542 \mathrm{e}^{+01}+7,722 \mathrm{e}^{-06} X_{1}+1,012 \mathrm{e}^{-17} X_{2} \\
-6,120 e^{-06} X_{4} \\
\widehat{Y}_{2}=2,567 \mathrm{e}^{+00}+6,483 \mathrm{e}^{-07} X_{1}-6,207 \mathrm{e}^{-05} X_{3} \\
+2,219 \mathrm{e}^{-02} X_{5}
\end{gathered}
$$

Berdasarkan model regresi SUR dapat menjelaskan bahwa:

Untuk model $\hat{Y}_{1}$

- Jika variabel upah minimum $\left(\mathrm{X}_{1}\right)$ naik sebesar satu rupiah maka IPM $\left(\mathrm{Y}_{1}\right)$ akan naik sebesar $7,722 \mathrm{e}^{-06}$. Jika variabel jumlah angkatan kerja $\left(\mathrm{X}_{4}\right)$ bertambah satu orang maka IPM ( $\left.\mathrm{Y}_{1}\right)$ akan turun sebesar $-6,120 \mathrm{e}^{-06}$ dan variabel prediktor yang berpengaruh signifikan terhadap IPM $\left(\mathrm{Y}_{1}\right)$ adalah upah minimum $\left(\mathrm{X}_{1}\right)$ dan Jumlah Angkatan Kerja $\left(\mathrm{X}_{4}\right)$ karena nilai $p$-value dari kedua variabel tersebut lebih kecil dari nilai alpha $5 \%$.

Untuk model $\widehat{Y}_{2}$

- Jika variabel upah minimum $\left(\mathrm{X}_{1}\right)$ naik sebesar satu rupiah maka laju pertumbuhan PDRB $\left(\mathrm{Y}_{2}\right)$ akan naik sebesar $6,483 \mathrm{e}^{-07}$ dan variabel prediktor yang berpengaruh signifikan terhadap laju pertumbuhan $\operatorname{PDRB}\left(\mathrm{Y}_{2}\right)$ adalah upah minimum $\left(\mathrm{X}_{1}\right)$ karena nilai $p$-value dari kedua variabel tersebut lebih kecil dari nilai alpha $5 \%$.

Pada Tabel 7 juga di dapatkan nilai $\mathrm{R}^{2}$ untuk model $\widehat{Y}_{1}$ sebesar 0,594 berarti 59,4\% IPM dapat dijelaskan oleh upah minimum, pendapatan asli daerah, dan jumlah angkatan kerja. Sedangkan untuk nilai $\mathrm{R}^{2}$ untuk model $\hat{Y}_{2}$ sebesar 0,285 berarti 28,5 \% laju pertumbuhan PDRB dapat dijelaskan oleh upah minimum, jumlah investasi pada industri besar dan sedang, dan tingkat partisipasi angkatan kerja.

\subsection{Uji Asumsi Model SUR}

Setelah dilakukan pemodelan SUR, maka perlu dilakukan pengujian asumsi residual Identik, Independen, dan Distribusi Normal (IDN).

\subsubsection{Uji Homoskedastisitas}

Pada Tabel 8 menunjukkan hasil pengujian homoskedastisitas dengan menggunakan uji Breush-Pagan.

Tabel 8. Breush Pagan Test

\begin{tabular}{llrc}
\hline & $\begin{array}{c}\text { Breush- } \\
\text { Pagan }\end{array}$ & $\begin{array}{c}\text { Chi-Square } \\
\left(\chi^{2}{ }_{k-1 ; 0,05}\right)\end{array}$ & Keputusan \\
\hline$\widehat{\boldsymbol{Y}}_{\mathbf{1}}$ & $* \mathbf{4 , 8 2 0 \mathrm { e } ^ { - 0 6 }}$ & 5,991 & $\begin{array}{c}\text { Gagal } \\
\text { Tolak } \mathrm{H}_{0}\end{array}$ \\
\hline$\widehat{\boldsymbol{Y}}_{2}$ & $* \mathbf{7 , 1 2 3 \mathrm { e } ^ { - 0 6 }}$ & 7,815 & $\begin{array}{c}\text { Gagal } \\
\text { Tolak } \mathrm{H}_{0}\end{array}$ \\
\hline
\end{tabular}

Keterangan: *) Signifikan pada $\alpha=5 \%$ 
Berdasarkan Tabel 8 untuk model SUR $\hat{Y}_{1}$ dan $\hat{Y}_{2}$ diperoleh nilai Breush-Pagan yang lebih besar dari nilai $\chi_{\boldsymbol{k}-\mathbf{1} ; \mathbf{0 , 0 5} \text {. Sehingga }}^{2}$ dapat dikatakan ragam error dari kedua model SUR tidak homogen dan tidak memenuhi asumsi identik.

\subsubsection{Uji Autokorelasi}

Pada Tabel 9 menunjukkan hasi pengujian autokorelasi dengan menggunakan uji Run Test.

\begin{tabular}{|c|c|c|c|}
\hline & $\begin{array}{l}\text { Durbin } \\
\text { Watson }\end{array}$ & p-value & Keputusan \\
\hline$\widehat{\boldsymbol{Y}}_{1}$ & 0,000 & $* 1,000$ & Gagal Tolak $\mathrm{H}_{0}$ \\
\hline$\widehat{\boldsymbol{Y}}_{2}$ & $-0,823$ & $* 0,411$ & Gagal Tolak $\mathrm{H}_{0}$ \\
\hline
\end{tabular}

Berdasarkan Tabel 9 untuk model SUR $\hat{Y}_{1}$ dan $\hat{Y}_{2}$ diperoleh nilai signifikansi RunsTest yang lebih besar dari $\alpha=5 \%$. Sehingga dapat dikatakan bahwa error dari kedua model SUR tidak terdapat autokorelasi dan telah memenuhi asumsi independen.

\subsubsection{Uji Normalitas}

Pada Tabel 10 menunjukkan hasil pengujian pengujian asumsi distribusi normal dengan menggunakan uji kolmogorovsmirnov.

Tabel 10. Kolmogorov-Smirnov Test

\begin{tabular}{lrrr}
\hline & Nilai $\boldsymbol{D}$ & $\boldsymbol{p}$-value & Keputusan \\
\hline$\widehat{\boldsymbol{Y}}_{\mathbf{1}}$ & 0,073 & $* \mathbf{0 , 8 7 7}$ & Gagal Tolak $\mathrm{H}_{0}$ \\
\hline$\widehat{\boldsymbol{Y}}_{\mathbf{2}}$ & 0,128 & $* \mathbf{0 , 1 2 3}$ & Gagal Tolak $\mathrm{H}_{0}$ \\
\hline Keterangan: $\left.{ }^{*}\right)$ & Signifikan pada $\alpha=5 \%$
\end{tabular}

Berdasarkan Tabel 10 untuk model SUR $\widehat{Y}_{1}$ dan $\hat{Y}_{2}$ diperoleh nilai $p$-value yang lebih besar dari $\alpha=5 \%$. Sehingga dapat dikatakan bahwa error dari kedua model SUR berdistribusi normal dan telah memenuhi asumsi distribusi normal.

\subsection{Ukuran Ketepatan Model SUR}

Pada pemodelan SUR diperoleh nilai dari hasil penduga parameter menggunakan koefisien determinasi $\left(\mathrm{R}^{2}\right)$ Mc-Elroy model SUR sebesar 0,461. Dimana nilai tersebut berada dalam batas $0 \leq R^{2} \leq 1$ sehingga ukuran kebaikan model SUR dapat dikatakan sudah cukup baik dan 46,1\% model SUR mampu dijelakan oleh variabel prediktornya.

\section{SIMPULAN DAN SARAN}

Berdasarkan analisis dan pembahasan yang telah dijelaskan mengenai pemodelan pemodelan IPM dan laju pertumbuhan PDRB sebagai faktor pertumbuhan perekonomian di Jawa Timur menggunakan metode Seemingly Unrelated Regression (SUR) memiliki kesimpulan sebagai berikut:

1. Pemodelan terhadap IPM dan laju pertumbuhan PDRB di Provinsi Jawa Timur dengan metode SUR diperoleh model SUR dari masing-masing variabel respon dan faktor-faktor yang diduga mempengaruhinya yaitu:

$$
\begin{gathered}
\widehat{Y}_{1}=5,542 \mathrm{e}^{+01}+7,722 \mathrm{e}^{-06} X_{1}+1,012 \mathrm{e}^{-17} X_{2} \\
-6,120 e^{-06} X_{4} \\
\widehat{Y}_{2}=2,567 \mathrm{e}^{+00}+6,483 \mathrm{e}^{-07} X_{1}-6,207 \mathrm{e}^{-05} X_{3} \\
+2,219 \mathrm{e}^{-02} X_{5}
\end{gathered}
$$

Dengan $\hat{Y}_{1}$ merupakan variabel respon untuk memprediksi IPM pada Kabupaten/Kota di Provinsi Jawa Timur. Faktor - faktor yang secara signifikan mempengaruhi IPM di tiap Kabupaten/Kota Provinsi Jawa Timur dengan tingkat signifikansi sebesar 5\% adalah upah minimum dan Jumlah Angkatan Kerja. Sedangkan $\hat{Y}_{2}$ merupakan variabel respon untuk memprediksi laju pertumbuhan PDRB pada Kabupaten/Kota Provinsi Jawa Timur. Faktor - faktor yang secara signifikan mempengaruhi laju pertumbuhan PDRB di tiap Kabupaten/Kota Provinsi Jawa Timur dengan tingkat signifikansi sebesar 5\% adalah upah minimum.

2. Ukuran kebaikan model SUR dengan menggunakan koefisien determinasi $\left(\mathrm{R}^{2}\right)$ Mc-Elroy sebesar 46,1\%, sehingga ukuran kebaikan model SUR dapat dikatakan sudah cukup baik.

Adapun saran yang diberikan penulis adalah untuk penelitian selanjutnya diharapkan dalam pemilihan variabel independen yang digunakan sebaiknya dikaji kembali sesuai dengan keilmuan IPM maupun laju pertumbuhan PDRB sehingga akan diperoleh hasil yang lebih baik.

\section{DAFTAR PUSTAKA}

Badan Perencanaan Pembangunan Nasional dan Departemen Dalam Negeri. 2019. Buku Pedoman Penguatan Pembangunan Daerah. Jakarta. 
Badan Pusat Statistik. 2018. Statistika Keuangan Pemerintah Desa 2018. Surabaya. BPS Provinsi Jawa Timur

Badan Pusat Statistik. 2019. Perkembangan Beberapa Indikator Utama SosialEkonomi Provinsi Jawa Timur 2019. Surabaya. BPS Provinsi Jawa Timur

Badan Pusat Statistik. 2020. Provinsi Jawa Timur Dalam Angka 2020. Surabaya. BPS Provinsi Jawa Timur.

Samad, Muh., dan Setiawan. 2011. Pemodelan Ketahanan Pangan Rumah Tangga di Indonesia dengan Pendekatan Seemingly Unrelated Regression Tahun 2007. Prosiding Seminar Nasional Statistika Universitas Diponegoro. ISBN: 978979-097-142-4.

Santosa, Agus Budhi, Nur Iriawan, Setiawan, dan Moh. Dokhi. 2013. Pemodelan Seemingly Unrelated Regression dengan Pendekatan Bayesian pada Sektor Utama di Jawa Timur. Prosiding Seminar Nasional Matematika dan Pendidikan Matematika, ISBN: 978-979-16353-94.

Todaro, Michael P. dan Stephen C. Smith.2004. Pembangunan Ekonomi di Dunia Ketiga, Edisi Kedelapan. Jakarta : Erlangga.

Zellner. 1962. An Efficient Method of Estimation Seemingly Unrelated Regression and Test for Aggregation Bias. Journal of the American Statistical Association 57:348-68

Adyria Fitriana $^{1}$, Wara Pramesti ${ }^{2}$, Elvira Mustikawati Putri Hermanto ${ }^{3}$, 